\title{
Micro-generation and micro combined heat and power generation using "free" low temperature heat sources through Organic Rankine Cycles
}

\author{
J. Navarro-Esbrî ${ }^{1,2}$, B. Peris ${ }^{1}$, R. Collado ${ }^{2}$, F. Molés ${ }^{1}$ \\ ${ }^{1}$ ISTENER Grupo de investigación de Ingeniería de los Sistemas Térmicos y Energéticos, \\ Campus Riu Sec- Universidad Jaume I, Av. de Vicent Sos Baynat, s/n, 12071 Castelló de la Plana, Spain. \\ Phone: +0034 964728 137, Fax number: +0034 964 728106, e-mail: navarroj@emc.uji.es, bperis@emc.uji.es, \\ franmoles.fmr@gmail.com \\ ${ }^{2}$ Expander-Tech, Universidad Jaume I de Castelló, Av. de Vicent Sos Baynat, s/n 12071 Castelló de la Plana, Spain \\ Campus Riu Sec, s/n- Universitat Jaume I, 12071 Castellón de la Plana, Spain.
}

Phone: +0034 964696 859, Fax number: +00 34964697 024, e-mail: info@expandertech.net, info@ rankweb.es

\begin{abstract}
The Organic Rankine Cycle (ORC) technology is an efficient way for small-scale generation. It offers great benefits from low temperature heat sources, recovering waste heat and revaluing renewable thermal energy.

This paper presents the use of ORC for power and combined heat and power generation from low temperature heat sources. Specifically, two recent applications successfully implemented in Spain are reported, based on Rank ${ }^{\circledR}$ technology: a micro generation for waste heat recovery in a ceramic industry using HT-20 kWe and a micro combined heat and power generation using solar heat with HT-C $5 \mathrm{kWe}$.
\end{abstract}

Experimental data have been evaluated to check economical and technical ORC feasibility. From waste heat recovery, now up to $23 \mathrm{kWe}$ are generated, $336 \mathrm{MWt}$ of primary energy are saved and 44 tonnes of $\mathrm{CO} 2$ emissions are avoided, with a suitable payback lower than 5 years. From renewable thermal energy, now $37 \mathrm{MWt}$ of primary energy are saved, 5 tonnes of $\mathrm{CO} 2$ emissions are avoided with a payback lower than 8 years.

\section{Key words}

Organic Rankine cycle (ORC), low temperature heat sources, micro generation, micro combined heat and power generation, energy efficiency.

\section{Introduction}

Thermal energy recovery, including low temperature heat sources, has been recently undertaken as an effective measure to improve energy efficiency.

Industrial plants continually reject large amounts of thermal energy through gaseous effluents or warm liquids during daily operation. These energy losses contribute to increase production costs and greenhouse gas emissions. A remarkable feature of the thermal energy rejected is its low potential for power conversion. The temperatures of the sources limit the maximum performance of any thermodynamic cycle, and therefore the electric energy capable of being generated. Moreover, the thermal power that can be obtained from these sources is limited and their combination may result too expensive. With this in mind, it is observed that the large majority of waste heat sources, associated with industrial processes, rarely exceed a theoretical electric power of $50-100 \mathrm{~kW}$.

Various thermodynamics cycles have been studied for the conversion of low-grade heat sources into electricity such as the organic Rankine cycle (ORC), supercritical Rankine cycle, Kalina cycle, Goswami cycle, and trilateral flash cycle. Their operation performance difference is only $3 \%$ against much less complex and minor maintenance required by the basic ORC [1].

Several works about ORC applications can be found in the literature [2],[3] and commonly are referred to theoretical studies or experimental tests [4]-[6]. However, in this work two real applications implemented in Spain based on Rank ${ }^{\circledR}$ technology are presented: a micro generation for waste heat recovery in a ceramic furnace and a micro heat and power generation using solar concentrators.

The aim of this paper is to show the feasibility of the micro-generation and micro combined heat and power (CHP) generation of the ORC technology, for low grade heat recovery in actual applications using commercial equipments.

\section{Organic Rankine Cycle Technology}

An ORC system is similar to a conventional Rankine cycle, but uses an organic fluid instead of water. In recent years, works were intensified on ORC, as it is being progressively adopted as a premier technology to convert low-temperature heat resources into power. Available heat resources are: solar energy, geothermal energy, biomass products, surface seawater and waste heat from various thermal processes [7]. 
This technology provides global benefits without using fuel, such as fossil energy savings, reduction of greenhouse gas emissions, decreasing thermal pollution and losses in the distribution grid. In addition to user-level benefits such as reduction of energy costs and improve of competitiveness.

The general use of ORC was focused on great power. However, micro-generation equipments have already been developed, with examples throughout the world for powers minor than $100 \mathrm{kWe}$. Highlighting equipments that generate at the same time electrical energy and useful heat up to $85^{\circ} \mathrm{C}$, as Rank ${ }^{\circledR}$ equipments are.

The economical and technical feasibility of the ORC equipments has been driven by a novel technology based on volumetric expanders, instead of the most commonly used turbines. These expanders are used in Rank® systems for their solutions up to $100 \mathrm{kWe}$. These equipments, Table I, cover the range of needs through three series:

\section{LT: Micro-generation activated with $T>85^{\circ} \mathrm{C}$ \\ HT: Micro-generation activated with $T>140^{\circ} \mathrm{C}$ \\ $H T-C$ : Micro CHP generation activated with $T>140^{\circ} \mathrm{C}$}

Table I. - Rank® equipments and applications

\begin{tabular}{|c|c|}
\hline Product & $\begin{array}{c}\text { Application } \\
\end{array}$ \\
\hline \multirow{5}{*}{$\begin{array}{l}\text { Rank@ LT: Product } \\
\text { range optimized for } \\
\text { electricity generation } \\
\text { with low activation } \\
\text { temperatures, from } 80- \\
90{ }^{\circ} \mathrm{C} \text {. }\end{array}$} & $\begin{array}{l}\text { Heat recovery from cooling systems } \\
\text { in cogeneration engines }\end{array}$ \\
\hline & $\begin{array}{l}\text { Heat recovery from compressor } \\
\text { refrigeration systems }\end{array}$ \\
\hline & $\begin{array}{l}\text { Waste heat recovery from } \\
\text { compressed air }\end{array}$ \\
\hline & $\begin{array}{l}\text { Heat recovery from thermosolar } \\
\text { facilities without concentrators }\end{array}$ \\
\hline & Geothermal energy recovery \\
\hline \multirow{5}{*}{$\begin{array}{l}\text { Rank } ® \text { HT: Product } \\
\text { range optimized for } \\
\text { electricity generation } \\
\text { with low activation } \\
\text { temperatures, greater } \\
\text { than } 140^{\circ} \mathrm{C} \text {. }\end{array}$} & Industrial waste heat recovery \\
\hline & $\begin{array}{l}\text { Heat recovery from concentrating } \\
\text { solar thermal facilities }\end{array}$ \\
\hline & $\begin{array}{l}\text { Waste heat recovery from smoke of } \\
\text { combustion boilers }\end{array}$ \\
\hline & $\begin{array}{l}\text { Waste heat recovery from smoke of } \\
\text { cogeneration equipments }\end{array}$ \\
\hline & Heat recovery from biogas plants \\
\hline \multirow{6}{*}{$\begin{array}{l}\text { Rank@ HT-C: } \\
\text { Product range } \\
\text { optimized for the } \\
\text { simultaneous } \\
\text { production of } \\
\text { electricity generation } \\
\text { and heat (warm water } \\
\text { to } 80^{\circ} \mathrm{C} \text { ) with low } \\
\text { activation } \\
\text { temperatures, greater } \\
\text { than } 140^{\circ} \mathrm{C}\end{array}$} & Industrial waste heat recovery \\
\hline & $\begin{array}{l}\text { Heat recovery from concentrating } \\
\text { solar thermal, in general and } \\
\text { insolated facilities }\end{array}$ \\
\hline & $\begin{array}{l}\text { Waste heat recovery from smoke of } \\
\text { combustion boilers }\end{array}$ \\
\hline & $\begin{array}{l}\text { Waste heat recovery from } \\
\text { cogeneration equipments }\end{array}$ \\
\hline & $\begin{array}{l}\text { Heat recovery from biomass boilers, } \\
\text { for general and isolated facilities }\end{array}$ \\
\hline & Heat recovery from biogas plants \\
\hline
\end{tabular}

\section{Analysis of ORC applications successfully implemented in Spain}

\section{A. Micro-generation in a Spanish ceramic industry through Rank® HT series}

The process of ceramics firing, as well as many other high temperature processes, is highly inefficient and it is possible to recover an important fraction of the heat input. However, the recovery of heat is not practical because heat finds little use in the factory and its transport to other users is expensive [8].

Often a fraction of the rejected heat has a very high thermal recovery potential due to their mass flow, moderate temperature and non corrosive composition. That is why the indirect air cooling furnace duct has the best conditions to integrate an ORC equipment.

An important constraint in the industrial sector to integrate an energy efficiency measure is the non-influence of the new facility in their original manufacturing process. In this way an air bypass was integrated for allowing maintenance operations and commissioning tests. The Fig. 1 shows the crossflow heat exchanger situated in the enabled by-pass. It was dimensioned to introduce an insignificant pressure drop less than $190(\mathrm{~Pa})$.

To establish the thermal energy capable of being recovered some measures with a flue gas analyzer during daily operations were made. Experimental data show that temperature was in the range of $220-270{ }^{\circ} \mathrm{C}$ and the air flow remains constant about $4.000 \mathrm{Nm}^{3} / \mathrm{h}$.

The reason is due to the change of the different performance curves that control the product residence time in the furnace. But it is not a problem, temperature decreases just as thermal power demanded by the dryer and the burners and, as is shown below, the machine is self-regulated according to available thermal energy.

In this way the heat exchanger was designed to recover an average thermal energy of $160 \mathrm{kWt}$

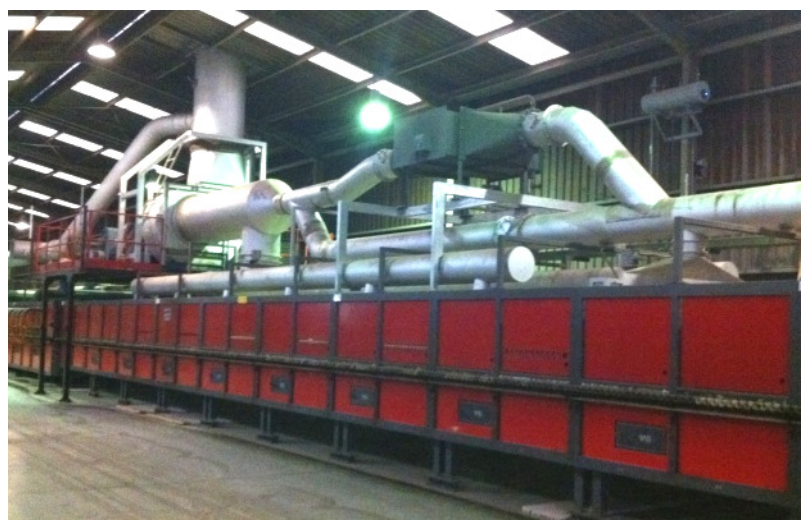

Fig. 1. Heat exchanger integrated in furnace chimney

Thermal oil facility is shown in Fig. 2. It was performed following the advice of the Spanish regulations for thermal fluids [9]. It is a closed circuit fed by a centrifugal 
pump to transport heat energy from the thermal source to the heat recovery unit.

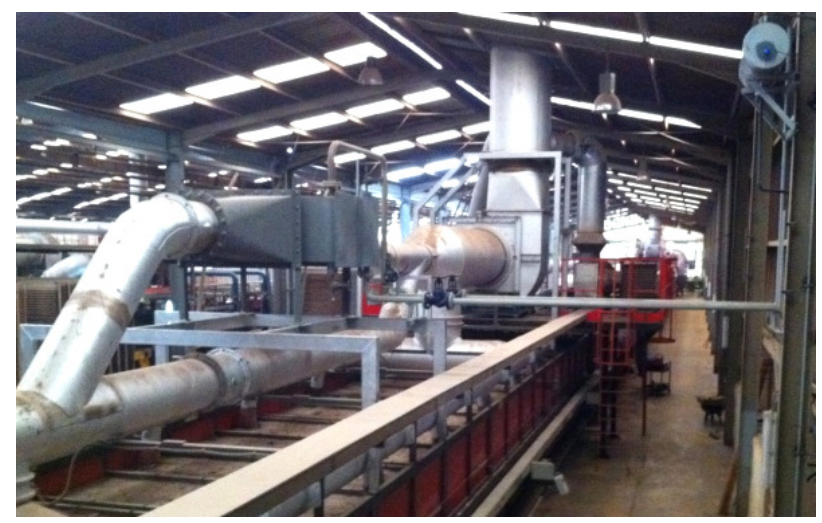

Fig. 2. Thermal oil facility

The diagram in Fig. 3 shows the main components of the installation: 1-thermal source, 2-ORC equipment, 3-feed pump, 4- expansion tank, 5-collection tank, 6- main safety valve, 7 -safety valve 0.5 barg, 8 - breaker vacuum valve, 9- minimum level sensor, 10-level viewer and purge valve.

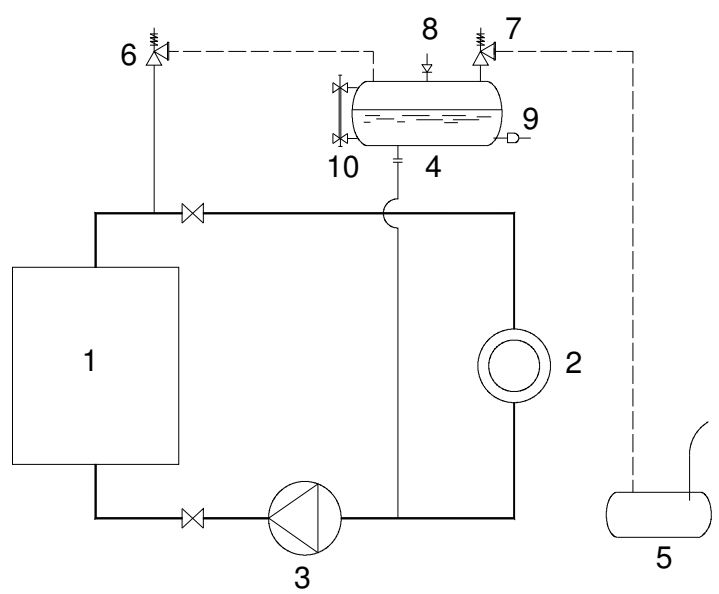

Fig. 3. Diagram of thermal oil facility

According to the application a Rank ${ }^{\circledR}$ HT-20 kWe equipment was selected, with the performance parameters listed in the following table.

Table II. - HT-20 kWe performance parameters

\begin{tabular}{|l|c|c|}
\hline \multicolumn{1}{|c|}{ Performance parameters } & Value & Units \\
\hline Rated heat source & 160 & $\mathrm{kWt}$ \\
\hline Operating range of thermal power & $100-200$ & $\mathrm{kWt}$ \\
\hline Rated electric power & 20 & $\mathrm{kWe}$ \\
\hline Activation temperature & $>120$ & ${ }^{\circ} \mathrm{C}$ \\
\hline Operating range of temperature & $120-200$ & ${ }^{\circ} \mathrm{C}$ \\
\hline Hours per year & 7.800 & $\mathrm{~h}$ \\
\hline
\end{tabular}

The equipment is installed outside of the factory due to the space available, as Fig. 4 shows. The dissipation to the environment is performed using air. Other researchers, already mentioned, which test ORC equipments in laboratories, [4]-[6], improve energy efficiency using cooling towers. But this solution may not always be the most appropriate in actual installations due to higher investment costs, higher maintenance and apparition of Legionella problems.

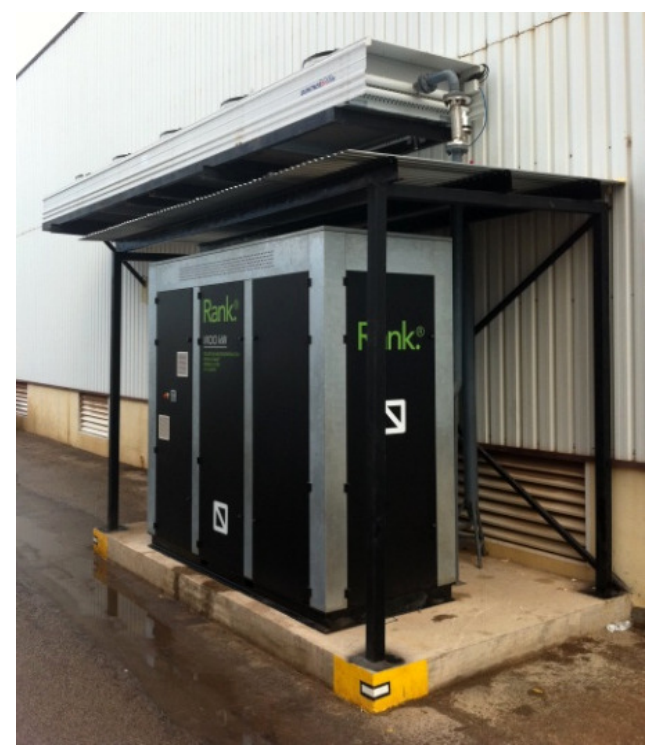

Fig. 4. Rank® ORC HT-20 kWe

Usually the machine works with soft external fluctuations that the ORC equipment absorbs automatically to maximize the thermodynamic cycle efficiency. External fluctuations appear in two ways: furnace temperature and ambient temperature.

The fluctuations are presented in the Fig. 5, with input and output parameters. It can be observed that when the ambient temperature is reduced, the backpressure of the expander tends to decline increasing the differential pressure and improving the thermodynamic efficiency of the cycle.

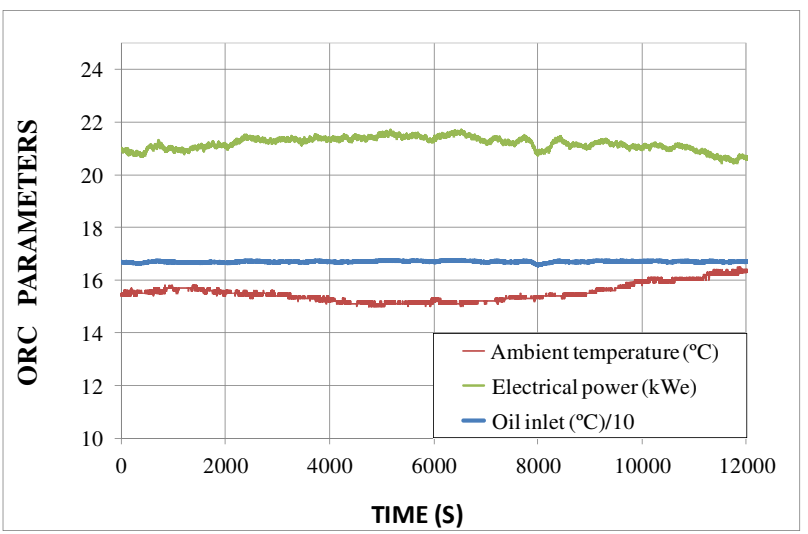

Fig. 5. ORC performance parameters

In usual operation of the furnace it can be observed the presence of material voids, reducing the waste heat and decreasing the thermal oil temperature more than $30^{\circ} \mathrm{C}$. As it can be appreciated in Fig. 6, the ORC machine continues generating power even with production voids, and getting back quickly to rated power. 


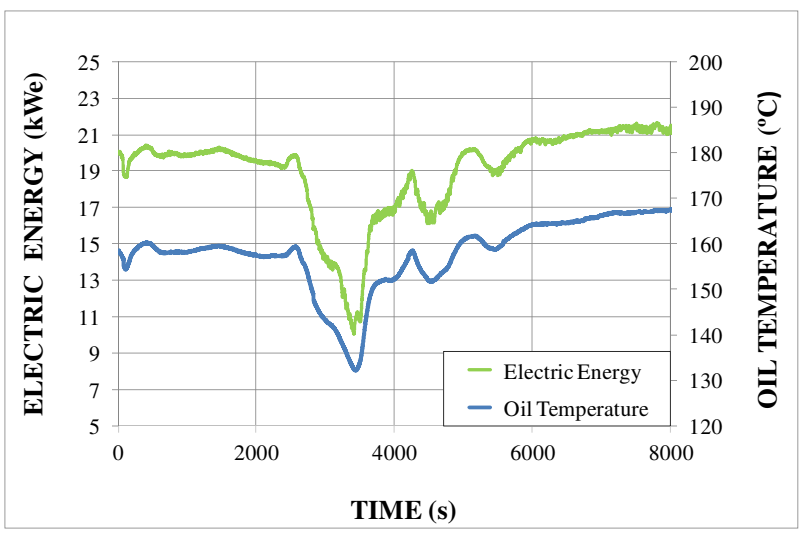

Fig. 6. Power generation with production voids

The experimental results show that Rank ${ }^{\circledR}$ HT-20 generates an average of $21 \mathrm{kWe}$. With an actual power depending on ambient and thermal oil temperatures, ranging from 19 to $23 \mathrm{kWe}$ (and $10-11 \mathrm{kWe}$ in production voids).

The electricity generated is consumed in the factory, saving the cost of consumption in the electric invoice. This ORC avoids 336 MWt of primary energy and 44 tonnes of $\mathrm{CO} 2$ emissions per year.

The economic study developed shows a payback for the installation, including all auxiliary elements, less than 5 years, with an annual benefit near $20.000 €$.

Next table includes certain economic indicators for the investment evaluation, assuming an ORC lifetime of 20 years.

Table III. - Economic indicators

\begin{tabular}{|l|c|l|}
\hline Net Present Value (NPV) & 103.000 & $€$ \\
\hline Internal Rate of Return (IRR) & 21 & $\%$ \\
\hline Payback Period & 4,6 & years \\
\hline
\end{tabular}

B. Micro combined heat and power generation implemented successfully in Spain through Rank® HT-C series

ORC is a cogeneration technology, such as covers the European DIRECTIVE 2004/8/EC [10], often classified in two types of cogeneration systems: bottom-cycling and top-cycling. Usually the low grade heat recovery is only associated with a bottom micro-generation configuration, as the previous application, but ORC also allows a top cycle use, like this one, generating power upstream the process.

It is an efficient measure to revalue thermal energy from renewable sources into useful heat with a thermal performance greater than $80 \%$, using this transformation to generate electrical power. The low cost of the ORC compared with the original facility allow to improve the economic indicators, enhancing the investment. Some examples can be seen in the literature for several applications through renewable energy like biomass [11] or geothermal [12].

In this context, a micro combined heat and power generation ORC was constructed and tested to revalue renewable solar energy obtained through solar concentrators, in hot water and electric energy simultaneously. An extra measure was adopted for the ORC, not only being designed for CHP, but also just electrical power when does not exist any thermal demand. The Rank ${ }^{\circledR}$ HT-C equipment is able to adjust automatically their operation mode according to demand, maximizing electrical power.

The basic scheme of the facility developed is shown in the Fig. 7. Parabolic concentrators receive solar energy and transfer it to a thermal fluid (thermal oil or pressurized water), that actives the ORC with a temperature higher than $140{ }^{\circ} \mathrm{C}$. The ORC generates a power output with a thermodynamic efficiency according to the heat sink.

If there is no thermal load the equipment dissipates to the ambient, only obtaining electrical generation. When the dissipation is directly made to the process (as useful heat) the backpressure increases reducing thermodynamic efficiency, although improving global efficiency.

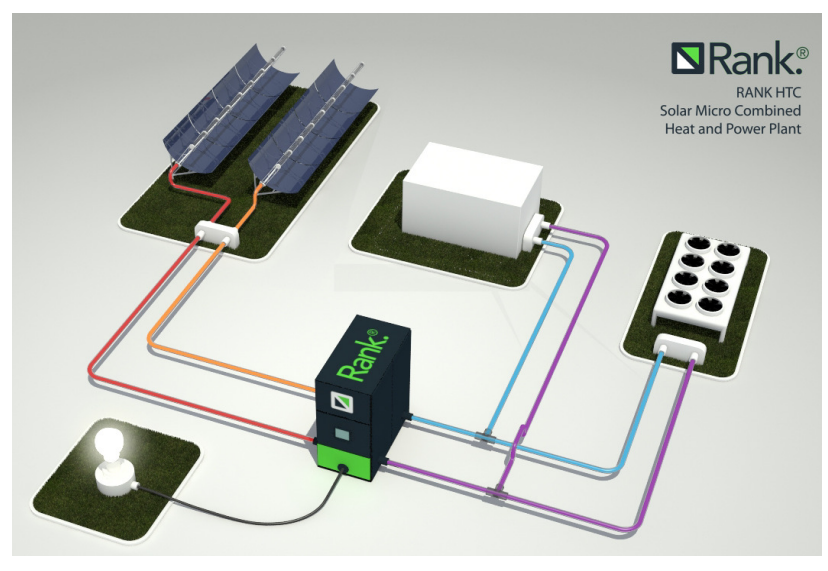

Fig. 7. Cogeneration facility through Thermosolar combined with Rank ${ }^{\circledR}$ HT-C

The Rank ${ }^{\circledR}$ equipment selected for this application was HT-C $5 \mathrm{kWe}$, with the operating parameters listed in Table IV.

Table IV. - HT-C 5 kWe performance parameters

\begin{tabular}{|l|c|l|}
\hline \multicolumn{1}{|c|}{ Performance parameters } & Value & \multicolumn{1}{c|}{ Units } \\
\hline Rated heat source & 60 & $\mathrm{~kW}$ \\
\hline Activation temperature & $>140$ & ${ }^{\circ} \mathrm{C}$ \\
\hline Operating range of electric energy & $4-7,5$ & $\mathrm{kWe}$ \\
\hline Useful heat generation & $50-55$ & $\mathrm{kWt}$ \\
\hline Hours per year & 3.000 & $\mathrm{~h}$ \\
\hline
\end{tabular}




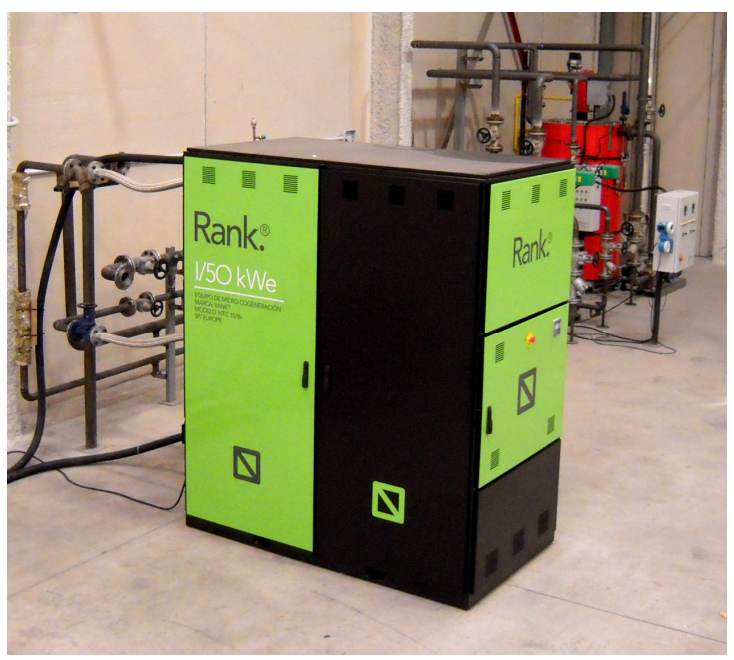

Fig. 8. Rank® HT-C equipment

The performance of the HTC equipment is characterized through experimental tests in laboratory, Fig. 8.

In this case, the heat sink becomes more relevant than in HT machines. To carry out the simulation of the useful heat consumption, a dissipation system with water as heat transfer fluid was made. The dissipation system consists of an air-cooler and an inverter to control the dissipation temperature being able to simulate the thermal loads from ambient temperature to $85^{\circ} \mathrm{C}$.

On-site actual installation, the change of operational modes is easier, it just needs an automatic valve which derives all the water flow to the air-cooler condenser in micro-generation mode, or derives it to the heat consumer in CHP generation mode.

Experimental data show in Fig. 9 that micro-generation mode provides greater electrical efficiency, with more than $7 \mathrm{kWe}$ and a dissipation about $30-35{ }^{\circ} \mathrm{C}$. In micro combined heat and power is much better the global efficiency with $4-5 \mathrm{kWe}$ and useful heat between $75-85^{\circ} \mathrm{C}$.

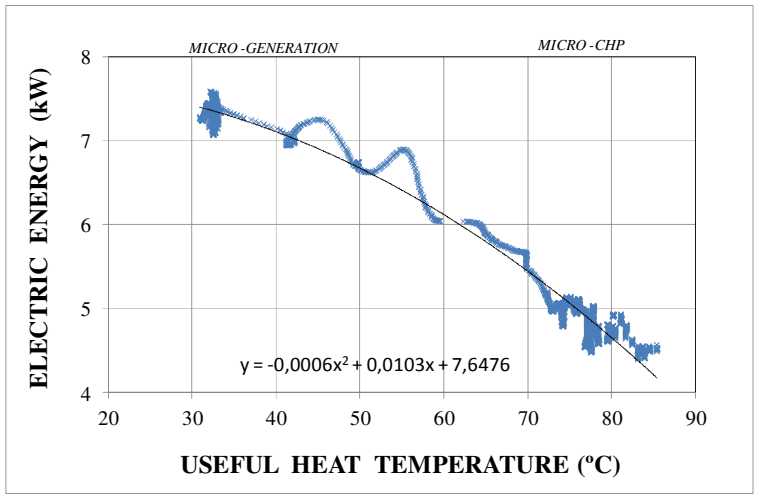

Fig. 9. Micro-generation and micro CHP performance

The results of the ORC integrated in the real application confirm that is possible to receive the same thermal power required by the process with higher performance, only with little changes in the original facility. From the previous heat, $37 \mathrm{MWt}$ of primary energy are saved now and about 5 tonnes of $\mathrm{CO} 2$ emissions are annually avoided.

The economic study developed shows a payback for the installation lower than 8 years, with an annual benefit of $2.520 €$ (only considering the benefits of the electricity generated).

\section{Conclusion}

The Organic Rankine cycle is a technology which allows easy integration in real applications. Nowadays already exist commercial equipments designed for a wide range of uses. In this paper a waste heat recovery from low grade thermal sources in a ceramic industry is proved with Rank® HT-20 equipment, with favorable performance results, generating up to $23 \mathrm{kWe}$, saving $336 \mathrm{MWt}$ of primary energy and avoiding 44 tonnes of $\mathrm{CO} 2$ emissions, with a suitable payback lower than 5 years.

A novel use of the ORC is successfully driven to turn renewable thermal energy into useful heat with a Rank $®$ HT-C $5 \mathrm{kWe}$, which allows optimizing the global efficiency of the facility with a self-regulation of its micro-generation mode and a micro combined heat and power generation mode. Technical feasibility has been verified in laboratory tests, simulating the heat and sink sources, with favorable performance results. It is expected in its annual operating mode a primary energy saves of 37 MWt and to avoid about 5 tonnes of $\mathrm{CO} 2$ emissions with a payback lower than 8 years.

\section{Acknowledgement}

The authors wish to acknowledge grants from the Ministry of Science and Innovation through the project IPT440000-2010-15 and the Conselleria de Industria, Comercio e Innovación of the Generalitat Valenciana through the project INIDIV2010022.

\section{References}

[1] H. Chen, D.Y. Goswami, E.K. Stefanakos, "A review of thermodynamic cycles and working fluids for the conversion of low-grade heat", Renewable and Sustainable Energy Reviews 14 (2010) 3059-3067.

[2] F.Vélez, J.J. Segovia, M.C. Martín, G. Antolín, F. Chejne, A. Quijano, "A technical, economical and market review of organic Rankine cycles for the conversion of low-grade heat for power generation", Renewable and Sustainable Energy Reviews 16 (2012) 4175- 4189

[3] B.F. Tchanche, Gr. Lambrinos, A. Frangoudakis, G. Papadakis, "Exergy analysis of micro-organic Rankine power cycles for a small scale solar driven reverse osmosis desalination system", Applied Energy 87 (2010) 1295-1306

[4] G. Pei, J. Li, Y. Li, D. Wang, J. Ji, "Construction and dynamic test of a small-scale organic rankine cycle", Energy 36 (2011) 3215-3223

[5] X.D. Wang, L. Zhao, J.L. Wang, W.Z. Zhang, X.Z. Zhao, W. $\mathrm{Wu}$, "Performance evaluation of a low-temperature solar Rankine cycle system utilizing R245fa", Solar Energy 84 (2010) 353-364 
[6] S.H. Kang. "Design and experimental study of ORC (organic Rankine cycle) and radial turbine using R245fa working fluid", Energy 41 (2012) 514-524

[7] B.F. Tchanche, Gr. Lambrinos, A. Frangoudakis, G. Papadakis, "Low-grade heat conversion into power using organic Rankine cycles - A review of various applications", Renewable and Sustainable Energy Reviews 15 (2011) 39633979

[8] C. Casci, G. Angelino, P. Ferrari, M. Gaia, G. Giglioli, E. Macchi. "Heat recovery in a ceramic kiln with an organic rankine cycle engine". Journal of Heat Recovery Systems Volume 1, Issue 2, 1981, Pages 125-131

[9] UNE 9-310-92. Instalaciones transmisoras de calor mediante líquido diferente de agua, CDU 536.2, noviembre 1992.

[10] DIRECTIVE 2004/8/EC OF THE EUROPEAN PARLIAMENT AND OF THE COUNCIL of 11 February 2004 on the promotion of cogeneration based on a useful heat demand in the internal energy market and amending Directive 92/42/EEC, 21.2.2004

[11] A. Stoppato, "Energetic and economic investigation of the operation management of an Organic Rankine Cycle cogeneration plant", Energy 41 (2012) 3-9

[12] F.Heberle, D.Brüggemann. "Exergy based fluid selection for a geothermal Organic Rankine Cycle for combined heat and power generation", Applied Thermal Engineering 30 (2010) $1326-1332$ 